\title{
ROHINGA STATELESS PERSONS: ROLE OF UNHCR IN REFUGEE PROTECTION AND LACK OF ADEQUATE LEGAL PROTECTION IN INDONESIA
}

\begin{tabular}{|c|c|}
\hline \multicolumn{2}{|c|}{$\begin{array}{l}\text { Sutiartono1; Jelly Leviza², Saiful Azam³ }^{3} \\
\text { 1,2,3Faculty of Law Universitas Sumatera Utara } \\
\text { Email: sutiarnoto@mail.usu.ac.id }\end{array}$} \\
\hline Article Information & Abstract \\
\hline $\begin{array}{l}\text { Submitted : } 28 \text { July } 2020 \\
\text { Reviewed : } 10 \text { August } 2020 \\
\text { Accepted : } 31 \text { August } 2020\end{array}$ & $\begin{array}{l}\text { This article aimed to study about how role of UNHCR in refugee protection } \\
\text { and the legal protection for Rohingya refugees in Medan municipality. } \\
\text { According to data from the United Nations High Commissioner for } \\
\text { Refugees (hereinafter abbreviated to UNHCR) since January 2012, there } \\
\text { were } 3275 \text { asylum seekers and } 1052 \text { refugees. Most refugees come to } \\
\text { Indonesia with the hope of being permanently resettled elsewhere, often in } \\
\text { America or Australia, but increasingly stringent immigration policies, } \\
\text { massive underfunding and a lack of resources to sustain the influx of } \\
\text { newcomers have left them stuck here. This research uses a sosio-legal } \\
\text { research with statute approach, conceptual approach, and case approach. } \\
\text { There are several provisions regarding refugees, but none have specifically } \\
\text { discussed the handling of refugees in Indonesia. The positive law of } \\
\text { immigration in Indonesia does not contain any special provisions (lex } \\
\text { specialis) for asylum seekers and refugees. Because Indonesia has not } \\
\text { ratified the } 1951 \text { Convention and 1967 Protocol, the Indonesian } \\
\text { government does not have the authority to deal with refugee problems. The } \\
\text { authority to handle refugees is given to international organizations such as } \\
\text { UNHCR which is a UN organization, IOM, ICRC and various other } \\
\text { organizations or NGOs engaged in the humanitarian sector. However, the } \\
\text { handling of this international organization has not been implemented } \\
\text { optimally due to obstacles }\end{array}$ \\
\hline
\end{tabular}

\section{Introduction}

The protection of international refugees stems from an understanding of human rights in general that every human being has the same rights and obligations. Likewise, the laws governing the treatment of refugees depart from international law regarding human rights. Therefore, talking about refugees cannot be separated from discussing human rights. Indonesia is one of the countries that has not yet signed the 1951 Refugee Convention and the 1967 Protocol. Even so, geographically, Indonesia is considered strategic for refugees and asylum seekers. Indonesia is a country in Southeast Asia which is located on the equator and is located between the Asian continent and the Australian continent. Given its location between two oceans and two continents, Indonesia is also known as the Archipelago (Kepulauan Antara). Indonesia is the largest archipelago country in the world, consisting of 17,508 islands. Geographically, Indonesia's strategic location makes Indonesia has an obligation to accept the consequences of being an open area to the outside world, especially those bordering the nearest country. This impact is 
in the form of the influx of thousands of asylum seekers who want to get refugee status (Mauna, Boer, 2005: 40) They entered through several borders in Indonesian territory.

According to data from the United Nations High Commissioner for Refugees (hereinafter abbreviated to UNHCR) since January 2012, there were 3275 asylum seekers and 1052 refugees. In 2019, there were 760 refugees in Indonesia which they placed in Canada, New Zealand, Australia and the US. As for the first five months of 2020, there were 404 refugees in Indonesia who had entered the settlement program. The existence of refugees and asylum seekers in Indonesia is nothing new. Their existence has existed since decades ago. During the President Suharto era, Indonesia became a destination country for Vietnamese asylum seekers and refugees in 1979 after Saigon (the capital of South Vietnam) fell under the hands of North Vietnam. Hundreds of thousands of people have left that region to seek refuge in other countries, either by various means through rivers, by air, or by sea.

Indonesia is not a party to the 1951 Convention on Refugees and the 1967 protocol, and there is no national law that regulates asylum seekers and refugees in Indonesia explicitly. As a transit country, Indonesia has carried out various efforts in terms of better handling of refugees, for example, ratifying multiple international human rights instruments (hereinafter abbreviated to HAM) and also producing national human rights instruments. These efforts are none other than Indonesia's commitment to upholding human rights (Suryokusumo, Sumaryo, 2005: 15). Indonesia does this as a member of the United Nations, which is morally responsible for implementing the Universal Declaration of Human Rights (UDHR) or the General Declaration of Human Rights (hereinafter abbreviated as DUHAM). This is also in line with the objectives of the State as stated in the preamble to the 1945 Constitution of the Republic of Indonesia, which states that one of the purposes of the State is to participate in implementing world order based on independence, lasting peace and social justice. Indonesia is not a party to the convention regarding refugee status in 1951 and the 1967 protocol. However, Indonesia is not directly obliged to handle refugees in Indonesian territory. In this case, UNHCR is the high commission at the United Nations for refugee affairs, which has the authority to deal with refugees in Indonesia.

One of the current refugee news is the Rohingya refugees. The Rohingya are a Muslim community who are a minority group living in Arakan, western Myanmar. The characteristics of the Rohingya people can be seen from the physical appearance, language, and culture, which shows the closeness of the Rohingya people to the South Asian community, especially the Chitagonian people. Over time since the Military Junta controlled Myanmar, Rohingya people have been subjected to various forms of violence 
and other acts that violate their human rights. Many of them, who were forcibly hired to build roads and military, were abused, and Rohingya's women became victims of rape.

The Myanmar government, which should be responsible for the Rohingya people, has taken a reverse stance and left the fate of the Rohingya people in a sadden condition. As a result, until now, there are still waves of flight and displacement from Rohingya people who have spread to various countries, including Indonesia (Mandalangi, J, 2004: 78). This condition causes the Rohingya people and also people from other ethnic minorities who come from different parts of Myanmar to become "stateless citizens" (residents who have lost their citizenship status). Unlike other ethnic groups whose citizenship is recognized by the Myanmar government. The Rohingya people are not considered citizens and suffer discrimination by the Myanmar government. In consequence, they flocked to leave Myanmar to get a better life. In contrast to Thailand's attitude of refusing and expelling its Rohingya refugees, the Indonesian government accepted and temporarily accommodated these refugees based on humanitarian reasons, even though Indonesia's domestic conditions were not very conducive. On the other hand, Thailand's actions in carrying out the expulsion clearly show inhuman behaviour. Even the latest news states that Thailand's government has forcibly sent home around 1,300 Rohingya Muslim refugees to their home country, Myanmar.

Based on research, the Myanmar government has not ratified either the 1951 refugee status convention and the 1967 protocol or conventions related to human rights such as the Universal Declaration of Human Rights, International Covenant on Economic, Social and Cultural Rights (ICESCR), International Covenant on Civil and Political Rights (ICCPR), Additional Protocol to the International Covenant on Civil and Political Rights (December 16 1966), Rome Statute of the International Criminal Court (Rome Statute), Convention on the Prevention and Punishment of the Crime of Genocide and Convention Against Torture and Other Cruel, in Human or Degrading Treatment or Punishment (United Nations, 2000: 30).

Refugees in Indonesia need protection. Protection of refugees is not only about granting asylum but in other forms, namely legal protection of their rights and also protection against violence and threats to be returned to their origin country. Learning from the Rohingya case, many issues can be benefited, considering that until now Indonesia has not yet become a party to the 1951 Geneva conventions on refugees and the 1967 protocol. Even though day by day, the number of refugees entering Indonesia is increasing, which in results will be a burden on the Indonesian government. Based on the introduction described, the author formulated two problems namely first problem, how 
is the legal protection for Rohingya refugees in Medan municipality and when did the Medan municipality Government accept refugees?

\section{Research Methods}

The study used normative juridical methods with secondary data. For this purpose, the data consists of legal texts, related literature, and pre-existing research documents (Soekanto \& Mamudji, 2003). The material of related literature includes relevant international legal instruments and literature in the form of textbooks, journals, and other supporting materials like dictionaries, encyclopedias, and other materials that provide additional information

\section{Research Result and Discussion}

\section{A. Aspects of Refugees Protection According to National Law}

Indonesia is a country that is not a party to the 1951 Conventions and the 1967 Protocol, and there are no laws in force in Indonesia that specifically address the issue of refugees. Even so, the Indonesian government cannot avoid its involvement with the problem of refugees in Indonesian territory. Besides, Indonesia is an active member of the United Nations (PBB). Indonesia has the responsibility and law to uphold the values of Human Rights (HAM) for both Indonesian citizens and people from other countries. We can see this from the 1945 Constitution of the Republic of Indonesia (Wagiman, 2012), the second principle of Pancasila which reads "just and civilized humanity", and the fourth paragraph of the opening of The 1945 RI Constitution and its amendments, as well as the Law No. 39 of 1999 on Human Rights, which clearly stated that the government of the Republic of Indonesia appreciates the protection, enforcement, fulfilment and advancement of human rights (Andi Ulfah Tiara Patunru, 2014: 67).

The problem of international refugees is no exception to the task of the government, especially for those international refugees that are in the territory of Indonesia. Several Indonesian laws address the issue of handling refugees, although there is no specific law that regulates refugees. Even though there is no specific legal provision that addresses refugees and asylum seekers, the issue of refugees has been discussed in several laws and regulations in Indonesia. However, the issue of refugees was discussed, causing the birth of Law Number 5 of 1998. Article 3 of Law Number 5 of 1998 states that:

"There should not be a State that refuses, returns, extradites a person to a country where there is a strong belief/reason that he or she will be in danger by being a subject to torture."

This issue is also discussed in Law Number 37 of 1999 on the Foreign Relations in Article 25 to Article 27. 
Article 25 of Law Number 37 of 1999 states:

1. The authority to grant asylum to foreigners rests with the President by taking into account the Minister's considerations.

2. The exercise of authority as referred to in paragraph (1) shall be regulated by a Presidential Decree.

Law Number 37 of 1999 on Foreign Relations in Chapter VI Articles 25-27, which have been used as a reference in granting asylum and handling refugees, does not explain precisely how the process of granting asylum and taking refugees that must be carried out by the Indonesian government. The regulations and laws made by the government are no longer able to answer the current problem of refugees in Indonesia.

The refugee handling mechanism in Indonesia depends on how we see the refugees and from what point of view. So far, the refugee problem in Indonesia has only been seen from an immigration point of view. The issue of refugees in Indonesia has not been seen from a human rights perspective. Refugees and asylum seekers are still equated with immigrants. However, the definitions between refugees, asylum seekers and immigrants are different from one another.

\section{B. Constraints Faced in Facing The Problems Of Refugees In Indonesia}

Handling refugees in Indonesia is experiencing difficulties due to several factors. Indonesia is the leading country for refugees as a transit country, especially to Australia. Several problems become obstacles to handle refugees in Indonesia. These obstacles include:

\section{The Non-Ratification of The 1951 Convention On The Determination Of Refugee Status And The 1967 Protocol.}

Indonesia has not been a party to the 1951 Geneva Convention on refugees and the 1967 protocol. States parties to the 1951 Convention have the responsibility and authority in determining the status and survival of refugees and all of its implications. As such, it is no longer UNHCR's authority to deal with refugee issues (Simon Behrman, 2019: 42-62). Indonesia's position as a non-state party to the 1951 convention caused Indonesia to have no obligation in dealing with the refugee problem. Under such conditions, Indonesia has not issued provisions that have juridical powers for refugees and asylum seekers. The Indonesian government does not have more involvement than as a temporary transit country. It helps find places for refugees until they are sent to the destination country that is offered or repatriated. 
By not being a party to the 1951 Convention and 1967 Protocol, the Indonesian government also does not have the authority to determine refugee status or what is commonly referred to as "Refugee Status Determination" (RSD), so the regulation of problems regarding refugees is determined by UNHCR (the UN deal with refugee matters) under the mandate it received under the UNHCR Statute of 1950. All States including those that have not ratified the Refugee Convention, are obliged to uphold refugee protection standards which are part of general international law because the convention has become jus cogens (Anna Katherine Boucher, (2019: 2533). No refugee can be returned to an area where his life or freedom is threatened.

Indonesia does not have legal protection for handling refugees. The number of refugees entering Indonesia is increasing. The absence of specific legal regulations regarding refugees has resulted in a legal vacuum in dealing with refugees. At the practical level, the absence of this legal instrument has created confusion and overlapping authority among interest institutions in dealing with issues relating to refugees and asylum seekers in Indonesia. With the absence of an operational, legal instrument to become a reference for interest institutions in anticipating refugee and asylum seeker problems, it is clear that refugee legal instruments need to be institutionalized in the national legal system in Indonesia.

\section{Lack of Adequate Legal Protection in Indonesia}

The problem of refugees in Indonesia is still positioned from an immigration point of view so that the issue of refugees is solely seen from an immigration perspective. The positive law of immigration in Indonesia does not contain any specific provisions (lex specialis) for asylum seekers and refugees. For example, there is no specific immigration administration procedure. There are no provisions regarding temporary residence permits, shelter, handling mechanisms and evaluation processes. Law Number 9 of 1992 concerning immigration which was drafted in the late 1980s has not made human rights an essential consideration as a standard in it.

The very nature of Indonesia's national legal framework relating to asylum seekers and refugees indicates that refugees, asylum seekers and stateless persons are treated as illegal immigrants, and threatened to be put to immigration detention centres (Rudenim) and are legally threatened with deportation. This leads to a dangerous situation because living in Indonesia runs the risk of being arrested and returned to a country where they experience fear of torturement (refoulement). 
For countries like Indonesia, which have immigration routes, they will see every foreigner's problem from an immigration point of view. Foreigners who enter Indonesia without travel documents are considered illegal. When referring to concrete cases, generally refugees or asylum seekers may not have complete travel documents because it is impossible for them to be forced to leave their country in advance to take care of visas, passports, or other documents. In most cases that occur, most of the refugees or asylum seekers do not have complete travel documents.

Article 31 of the 1951 Convention states that it is mandated not to allow refugees or asylum seekers who enter a country to be detained or punished. This can be resolved through refugees or asylum seekers reporting to an authorized official, stating the reasons why they entered the country concerned illegally (Jacobsen, $K, 1996: 655)$. Because Indonesia is not a country that ratifies the 1951 Conventions and the 1967 Protocol, Indonesia could impose penalties on them. However, based on the cooperative relationship that exists between immigration and UNHCR, the immigration authorities will immediately notify the UNHCR, which will then interview asylum seekers to determine their status as a refugee or not (Chambers, $R, 1986: 247)$

The usual mechanism for handling refugees in Indonesia is to report to the local police. Then, the local police will report to the National Police Headquarters. The National Police Headquarters reported to the Ministry of Foreign Affairs which then informed the UNHCR representatives in Indonesia. Furthermore, UNHCR officers will conduct interview sessions and place them in a place that is funded by UNHCR. Supposedly, the handling of those who claim to be on the front lines is immigration. The problem is that in Indonesia, the Immigration Reporting Points (TPI) are only located in a few big cities, so if in remote places such as near the coast, the local area should be first met, namely the village head.

Police officers are encountered solely because of practicality, as a police station, it is easier to find anywhere compared to immigration. Since Indonesia is not a signatory to the 1951 Refugee Convention, the government has allowed two international agencies to deal with asylum seekers: the United Nations High Commissioner For Refugees (UNHCR) office which oversees the process of determining refugee status, resettlement to third countries, and repatriation. The International Organization for Migration (IOM) who is responsible for providing day-to-day assistance, including food, investigations, accommodation and health care; Asylum seekers and refugees are the responsibility of IOM until they are assigned to a third country or voluntarily return to their origin country. Both UNHCR Indonesia and IOM Indonesia are severely under-resourced and have a high workload. 


\section{Determination of Status as Refugees}

UNHCR operates in Indonesia with the approval of the government of the Republic of Indonesia. The Director-General of Immigration for Indonesia issued an instruction in 2010 (No: IMI-1489.UM.08.05) which stated that persons seeking asylum or refugee status should be referred to UNHCR to participate in the process of determining refugee status and that "the status and presence of person foreigners holding Attestation Letters or identity cards issued by UNHCR as asylum seekers, refugees or persons served by UNHCR, must be respected " (Martin, A, 2005: 337). People who do not have these documents will be threatened with being admitted to an Immigration Detention Center, subject to fines, and/or deportation.

Although UNHCR operates in Indonesia with permission from the Indonesian government, its capacity is minimal due to the increasing number of asylum seekers seeking assistance in Indonesia. UNHCR has 60 staffs in Indonesia. Registered asylum seekers can apply for recognition of their status as refugees assessed by UNHCR through a process known as the Refugee Status Determination (RSD) procedure. Asylum seekers are interviewed by RSD officers assisted by a translator regarding their application for protection. When applications for protection are rejected, RSD procedures still provide one more opportunity to appeal the unfavourable decision.

In general, legal assistance and advice are not provided, so many of these adverse decisions are the result of asylum seekers did not understand the processes they are required to follow, as a result of language barriers, fear of speaking to the authorities, and because they do not know their rights and responsibilities as the person applying for refugee status. In practice, the right to legal counsel for asylum seekers and refugees has not been fully recognized by UNHCR and the government. This jeopardizes the integrity of the RSD process as asylum seekers are not fully aware of their rights and responsibilities, nor the operations that involve them. Research conducted by academics from Australia shows that there are several legal aspects of the protection needs of asylum seekers in Indonesia that should be addressed. One solution proposed was to provide independent legal assistance because "most of the asylum seekers and refugees interviewed appeared to have little understanding of the legal substance of their cases or of the procedures for determining refugee status by UNHCR in Indonesia" (Taylor and Rafferty- Brown, 2010).

\section{Placement to a third country}

Voluntary repatriation (if the conflict in the person's origin country has been resolved) and reunification with the local community is not an option in Indonesia 
because the Indonesian government does not allow refugees who have received UNHCR recognition as refugees to stay in this country.

In 2013, 898 people had left Indonesia to be placed in third countries. This is the highest number of placements from Indonesia in the last ten years. As of December 31, 2013, another 88 refugees have been accepted for placement in a third country and are awaiting departure, while another 966 cases have been submitted by UNHCR for consideration of placement, and are awaiting a decision from the country concerned (Jacobsen, K, 2002: 578). However, other 2,152 refugees are still awaiting submission or re-submission of their cases by UNHCR to third countries.

\section{Lack of Assistance Services}

The limited capacity of UNHCR in Indonesia to treat an increasing number of asylum seekers and the lack of places for deployment to third countries results in long waiting times. The lack available information assistance to asylum seekers and refugees to help themselves or their families results in frustration and depression for many of the people it serves.

Asylum seekers and refugees can only receive services from the International Organization for Migration (IOM) through a referral from immigration officials. As a result, many of them become displaced. Asylum seekers and refugees in Indonesia are also unable to obtain local identity documents such as official status permits known as identity cards (KTP), or national identity cards (Riyanto, S, 2004: 67). Without that document, they cannot work illegally. The absence of an exact legal status also often limits their ability to obtain social services such as health and education facilities, the inability to send their children to school, as stated by many families of asylum seekers and refugees, which very concerning. Asylum seekers and refugee children who were born while their parents were in Indonesia were also unable to obtain birth certificates. Some groups of asylum seekers and refugees are very vulnerable to becoming homeless. Families with young children and unaccompanied children, for example, are, particularly at risk. Other vulnerable groups in Indonesia include those who have experienced abuse and trauma, people with disabilities or those with mental health problems, single women and teenage girls.

\section{Immigration Detention Center}

Immigration Detention Centers (Rudenim) are increasingly being used as places to accommodate immigrants, including refugees, asylum seekers and stateless persons who would not normally be in a position to find the "normal" migration route. The Asia 
Pacific Refugee Rights Network (APRRN) has emphasized the following concerns about Immigration Detention in the region (Krustiyati, A, 2012: 173):

a. Use of arbitrary and unnecessary detention that does not meet international standards

b. Disregard for fundamental rights

c. Restrictions on asylum and legal aid procedures, and

d. Detention of vulnerable groups such as children, unaccompanied children, pregnant women, the elderly, and people with physical and mental health disorders.

Indonesian Immigration Detention Centers are run by the Indonesian government, but the system does not have adequate oversight mechanisms, which not transparent or has no complaints procedure. This makes violations of human rights a common occurrence.

Indonesian law states that citizens of other countries can be detained if they enter and stay in this country without the required documents. There are no criteria as to who should (or should not) be detained, and for how long. Some regulations permit the release of particular groups of people from Immigration Detention Centers, such as children, to be handled by international organizations (such as the International Organization for Migration or partner agencies of UNHCR). UNHCR has reported that as of December 31 2013, there were 1,773 people in Indonesian Immigration Detention Centers (Syahrin, M. A, 2019: 897), including 1,137 asylum seekers and 636 refugees. Of those detained, 274 were women, and 297 were children (and 87 of them were unaccompanied children).

\section{The legal basis for UNHCR's authority in its contribution to protect refugees in various countries, including Indonesia?}

From July 1947 to January 5 1951, the IRO had hosted more than one million refugees, returned 73,000 refugees to their countries of origin, and made plans for another 410,000 refugees to be moved within their own country. The refugees came from 30 countries, mostly from Eastern Europe. With the increasing number of refugees, the UN general assembly saw that international efforts were urgently needed, namely the establishment of a special agency to deal with refugee issues and international regulations that specifically regulate refugees. According to resolution 319A (IV), on December 3 1949, the general assembly decided to establish the office of the High Commissioner for UN Refugees in Geneva. The High Commission, namely the United Nation High Commissioner for Refugee (UNHCR), was founded in 1950 and only carried out its mandate in 1951 after the dissolution of the IRO. An essential point in the development of international Refugee Law, the IRO has established several criteria for 
refugees who can provide assistance and protection that are not based on their national group, namely:

a. Victims of Nazi, Fascist or Quisling (traitor) regimes which had opposed the allies;

The mandate above takes into account the existence of two aspects that are related to each other and cannot be separated regarding the UNHCR's duties, namely:

1. Providing international protection and

2. Seeking a permanent solution to the problem of refugees.

To carry out this mandate, the criteria that must be used as a measure for a refugee must be set out in article 1 of the 1951 Refugee Status Convention:

'... Is a person who, because of fear of persecution arising from his race, creed or political philosophy, is living outside his former home country and is unable or unwilling to avail himself of that country's protection.'

The concept of protection provided by UNHCR puts more emphasis on developing international instruments for the benefit of refugees and ensuring that they get treatment under the provisions of international legal instruments for the benefit of refugees, especially concerning the right to work, social security, and the right to obtain or use travel facilities. UNHCR's function in taking international steps is through coordination, liaising with governments, UN specialized agencies, NGOs and intergovernmental organizations. UNHCR seeks permanent solutions to refugees through voluntary repatriation. UNHCR, which performs an international protection function, that is trying to ensure respect for the fundamental rights of refugees, including the responsibility to seek asylum and ensures that no one is forcibly returned to a country where he or she is afraid of torture. Other forms of assistance provided by UNHCR are:

1. Help during major emergencies involving the movement of large numbers of refugees;

2. Regular programs in such fields as education, health and shelter;

3. Assisting to promote the self-sufficiency of refugees and their integration in host countries;

4. Voluntary repatriation;

5. Resettlement in third countries for refugees who cannot return to their homes and whose face protection problems in the country when they first sought asylum.

In humanitarian financing activities, UNHCR receives funding from the United Nations, government individuals, as well as other sources.

\section{UNHCR's Role in Addressing Refugees}


UNHCR is an international organization based in Geneva, Switzerland. This organization is a UN commission that deals specifically with refugees. This agency was founded on December 14 1950, by the UN General Assembly and began work one year later, on January 1 1951, to be precise. UNHCR initially only helped provide security protection, food, and medical assistance in an emergency. Besides that, it helps in finding solutions for refugees for an extended time, including helping to return them to their home countries or finding a new country for them so they can start a new life again. $\mathrm{UNHCR}$ is an agency that replaces the previous refugee agency (IRO agency). The International Refugees Organization (IRO) was the first agency established to deal with refugees. However, the existence of this institution was very short, from 1947 to 1952. On this basis, the international community also assumed that the presence of the UNHCR agency at that time would have the same fate. This pessimistic attitude is based on three reasons. First, the eastern bloc (the Soviet Union and its allies) did not participate in the UNHCR discussion (Syahrin, M. A, 2019: 1-4). Second, western blocs split between American and European attitudes. Third, UNHCR was formed by the western blocs whose tendency was only for the interests of these countries.

Since its establishment, UNHCR has served to provide protection to refugees and collaborate with governments around the world to find long-term solutions to problems faced by refugees. This was confirmed by Goodwin Gill who said: "UNHCR has a unique statutory responsibility to provide international protection to refugee and, together with government, to seek permanent solutions to their problems" (Atik Krustiyati, 2008). The various protection functions are described in the UNHCR statute, including the oversight of its legal instruments. Over the past five decades, UNHCR has more than 5000 staff serving in more than 120 countries. Currently, UNHCR is working with more than $20,000,000$ refugees. UNHCR is given the authority to provide international protection for refugees and seek to provide solutions to various problems faced by refugees. This institution periodically reports its work results before the UN General Assembly.

\section{E. The role of the UNHCR Medan representative in protecting refugees in North Sumatra Region?}

Officials of the United Nations High Commissioner for Refugees (UNHCR) visited a centre for refugees and asylum seekers belonging to the North Sumatra Provincial Government. The North Sumatra Provincial Government is the only province that works together to provide shelter for refugees and asylum seekers who are underage. This was stated by Thomas Vargas as UNHCR Representative in Indonesia, accompanied by UNHCR Indonesia Program Officer Ayaz Khan during his official visit to the Provincial Government of Indonesia, at the Governor's Office on Thursday. They were accepted by 
Plh. Regional Secretary of Provsu Hj. Sabrina, who on that occasion was accompanied by the Head of the Education Office, Drs. Masri, Head of the Communication and Informatics Office, Jumsadi Damanik, Aldo Sitompul from the Provincial Social Service and Muhammad from the Kesbangpolinmas.

Thomas Vargas expressed his official visit to North Sumatra to introduce himself and express his gratitude for the cooperation of the Provincial Government for being willing to accommodate refugees. He explained, in addition to visiting North Sumatra, his party also visited refugee shelters, including those located in Padang Bulan and the North Sumatra's special children's shelter facility in Stabat on Friday.

On this occasion, Plt. The Provincial Secretary expressed his appreciation for UNHCR's official visit. He explained that since 2013 the Provincial Government had accommodated the request of the Ministry of Law and Human Rights to provide shelter for refugee children who seek asylum.

The provincial government then changed the Education and Training Center Building in Stabat to become a residence for child refugees. During the two years of its existence, 100-200 refugee children left and entered the refugee camps with the capacity to assist the 42 children. It was explained that the accommodation needs of children under the age of 18 were met by the International Organization for Migration (IOM). Besides, social workers and health offices also take part in meeting education and health needs.

\section{Handling Of Rohingya Floods By Immigration Parties In Medan City.}

In Medan, North Sumatra, the Rohingya who were housed in the Medan Rudenim were mostly Rohingya previously housed in Aceh. They were transferred from temporary shelters in Aceh to Rudenim Medan, North Sumatra and Rudenim Tanjung Pinang Riau Islands. When a fact-finding was conducted at the Medan Rudenim, there were 84 Myanmar detainees, 45 Rohingya and 39 Myanmar non-Rohingya. Out of 45 Rohingya, 31 were men and five boys, five girls and four girls. The youngest is 8 (eight) years old named Nur Elhan. Nur Elhan is the second child of Nazirudin and Lily Jan. Nazirudin himself has lived in Malaysia for about 23 years. They married in Malaysia and have a refugee card from UNHCR Malaysia. Nazirudin decided to leave Malaysia and go to Indonesia because, in Malaysia Nazirudin's children, namely Nur Elhan 8 (eight months) and Nur Bibi Jan (4 years) could not go to school. Hence, Nazirudin decided to go to Indonesia with the hope that their children could get an education in Indonesia.

The condition of the holding room at Rudemin Medan is physically like a detention centre with narrow spaces and iron bars. Three people initially occupied the room measuring approximately $2 \times 4$ meters, but due to limited space, one place was 
occupied by six detainees. Even the number of detainees 266 people had exceeded the capacity of the Rudenim, even the official residence of the head of the Rudenim which was next to the detainee rooms was finally occupied by Nazirudin's family and their very young children. Operationally the Medan Rudenim has a limited budget for handling detainees. Therefore, the implementation of the daily operations of Rudenim Medan is assisted by the intergovernmental agency IOM (International Organization for Migration). IOM and UNHCR are also conducting assessments of Rohingya immigrants regarding the granting of international refugee status. In Medan, Rohingya, who has received International Refugee status from UNHCR, can stay outside the detention centre. They live on Jalan Cempaka, in Budget Hotels and Hotel Pelangi in Padang Bulan. Each month they get "pocket money" from IOM, which is about 1.2 million rupiahs, per person per month. Those who live outside the detention centre can do normal activities like other ordinary citizens while waiting for certainty of placement in a third country. Meanwhile, those who are inside the detention centre are waiting for the assessment from UNHCR and IOM. While in the detention centre they receive food, health and consultation facilities from IOM and UNHCR. However, in practice, the process of assessment and placement in a third country is not easy. Some Rohingya detainees have been detainees for three years as detainees for the Medan Rudenim and have not received refugee status from the UNHCR. There are even Bangladeshi detainees who have been in detention centres for seven years in Medan.

In August 2015 it was estimated that the number of Rohingya refugees in Medan is 305, four-person placed in the Immigration Detention Center in Medan City. Ninetytwo people were assigned to the Pelangi Hotel in Medan City, 31 people were at the Top Inn Hotel. The rest are placed in Wisma YPAP I, Hotel Sentabi and Hotel Beraspati, all of which are located in the city of Medan.

The problems that can be elaborated from the fact-finding data regarding the actual condition of Rohingya Refugees in Aceh, Medan and Tanjung Pinang, among others, arise from within and from outside. Problems that arise from within include that Indonesia is not currently a member country of the 1951 Vienna Convention on the Status of Refugees so that Indonesia does not have the obligation and authority to take international action against Rohingya immigrants who enter Indonesia (Atik Krustiyati, 2012). The implication is that Indonesia can only accommodate these immigrants for a maximum time limit of 10 (ten) years without being able and not having the right to take further action regarding the status of Rohingya immigrants who enter the territory of Indonesia. 
It is understandable why Indonesia has not yet been willing to ratify the Convention. The principle adhered to by Indonesian immigration is that foreigners who enter Indonesian territory must provide benefits for Indonesia, not the other way around "making Indonesia difficult". Indonesia is worried that if ratifying the Convention will have an impact on security stability and Indonesia's responsibility to take care of other citizens who come to seek asylum (asylum seekers). Immigrants will "flock" to Indonesia to seek asylum when Indonesia has ratified the Vienna Convention. However, even though Indonesia is not a member country of the 1951 Vienna Convention ratification, but as an international community, Indonesia cannot arbitrarily refuse immigrants who come to ask for asylum, especially if the security conditions in their home countries do not allow these immigrants to return to their home countries.

This then becomes Indonesia's dilemma in dealing with immigrants who enter Indonesia. Therefore, immigrants who are detained at the detention centre can stay in the detention centre for years because of the lengthy assessment process carried out by UNHCR for Rohingya immigrants to obtain status as international refugees. Besides that, the arrival of Rohingya people to Indonesia does not necessarily qualify as a refugee, because someone categorized as an international refugee must meet the requirements as stipulated in the 1951 Vienna Convention. Rohingya people in Indonesia are classified as Asylum-Seeking Immigrants. His status as an asylum-seeking immigrant is undoubtedly different from his position as an international refugee both in terms of rights and obligations. The unclear status of Rohingya immigrants who entered Indonesia contributed to the lengthy assessment process for Rohingya to obtain status as International Refugees.

Apart from internal problems, problems also arise from the outside, including:

1. The difficulty of repatriating Rohingya immigrants to Myanmar due to worsening security conditions;

2. The Myanmar Embassy in Indonesia is utterly indifferent to the Rohingya issues because they do not recognize Rohingya as Myanmar citizens;

3. Rohingya do not have passports so that it becomes an obstacle in the assessment process to become international refugees;

4. Rohingya do not want to be sent home because of the security conditions of Myanmar;

5. No third country has yet to accommodate Rohingya refugees;

6. Rohingya are not IOM's priority immigrants, which slows down the process of assessing their status as refugees; 
7. The length of time the Rohingya are accommodated in Indonesia is a burden on the State;

8. Many Rohingya are married to Indonesian women and have children and hope to become Indonesian citizens;

9. Many Rohingya have fake UNHCR refugee cards;

10. In the detention centre, Rohingya immigrants are detainees who are lazy and like to spill food if they do not like it;

11. Rohingya refugees living outside the detention centre often create problems;

12. Rohingya immigrants do not speak Malay or English, so it is difficult to carry out immigration actions.

In practice, although Indonesia did not ratify the 1951 Vienna Convention, Indonesia implemented several administrative regulations concerning the handling of refugees substantially, namely the Prime Minister's Circular Letter No. 11 / RI / 1956 dated September 7 1956, concerning Protection of Political Escape, Presidential Decree Number. 38 of 1979 concerning Coordination for the Resolution of Vietnam Refugee Problems, Presidential Decree Number. 3 of 2001 concerning the Coordinating Agency for Disaster Management and Refugee Management, and the Decree of the Minister of Justice and Human Rights of the Republic of Indonesia Number: M.05.H.02.01 of 2006 concerning Immigrant Detention Centers.

\section{Conclusion}

There are several provisions regarding refugees, but none have specifically discussed the handling of refugees in Indonesia. The positive law of immigration in Indonesia does not contain any special provisions (lex specialis) for asylum seekers and refugees. Because Indonesia has not ratified the 1951 Convention and 1967 Protocol, the Indonesian government does not have the authority to deal with refugee problems. The authority to handle refugees is given to international organizations such as UNHCR which is a UN organization, IOM, ICRC and various other organizations or NGOs engaged in the humanitarian sector. However, the handling of this international organization has not been implemented optimally due to obstacles. These constraints include limited funds, the length of placement in a third country, the lack of adequate legal regulations in Indonesia, and immigration detention centres that exceed the capacity and treat refugees improperly Indonesia also has its considerations which are the reasons Indonesia has not ratified the 1951 Convention and the 1967 Protocol. The reason is that if the government decides to ratify the 1951 Convention and 1967 Protocol, the government must increase the power of law in Indonesia. One of them is by 
increasing border surveillance and maritime defence and security. Marine protection and security certainly require the procurement of equipment and weapons that are complete and in good condition, for officers patrolling the sea and border areas of Indonesia.

Rohingya ethnicity is one of the most significant conflicts in Myanmar history. The conflict began between the Rohingya and the Myanmar Military Junta government. The Myanmar Junta government does not recognize the Rohingya ethnicity who are mostly in the Rakhine region as one of the ethnic groups residing in Myanmar. This can be proven by the discriminatory law made by the Myanmar government, namely "Burma Citizenship Law 1982" which contains one of the articles which states that the government has the right to determine which citizens are and which are considered noncitizens which causes the Rohingya to lose their citizenship. The inhuman treatment of the Myanmar government caused them to evacuate. Indonesia also faces the problem of Rohingya refugees who are stranded in Indonesia, one of which is the Medan municipality. The handling of Rohingya refugees in Indonesia is carried out by immigration assisted by international organizations such as UNHCR, IOM, and ICRC by placing them in the Immigration Detention Center (RUDENIM) and various other places to accommodate them. The role of UNHCR is to record the number of Rohingya refugees in Medan and determine their status as refugees by conducting interviews.

\section{BIBLIOGRAPHY}

\section{Books:}

Mandalangi, J. (2004). Segi-Segi Hukum Organisasi Internasional, Bandung: Binacipta.

Mauna, Boer. (2005). Hukum Internasional: Pengertian, Peranan Dan Fungsi Dalam Era Dinamika Global. Bandung: Alumni.

Suryokusumo, Sumaryo. (2005). Hukum Organisasi Internasional. Bandung: Fakultas Hukum Universitas Padjadjaran.

United Nations. (2000). Basic Facts About United Nations. New York.

Wagiman. (2012). Hukum Pengungsi Internasional. Jakarta: Sinar Garfika.

Andi Ulfah Tiara Patunru. (2014). Peranan United Nation High Commisioner for Refugees (UNHCR) terhadap pengungsi korban perang saudara di suriah (skripsi). Makassar: Fakultas Hukum Universitas Hasanudin Departemen Hukum Internasional. 
Lembar disposisi Direktur HAM dan Kemanusiaan. (2010). Naskah Akademik Rancangan Undang-undang Pengesahan Konvensi Pengungsi. Jakarta: Direktorat kerjasama HAM Kementerian Hukum dan Hak Asasi Manusia Republik Indonesia.

Training Module RLD June 11992 UNHCR, An Introduction to the International Protection of Refugees.

\section{Journals:}

Simon Behrman. (2019). Refugee Law as a Means of Control. Journal of Refugee Studies, Vol. 32, Issue 1 (March 2019), pp. 42-62. DOI: https://doi.org/10.1093/jrs/fey016

Anna Katherine Boucher. (2019). How 'skill' definition affects the diversity of skilled immigration policies. Journal of Ethnic and Migration Studies, Vol. 46, Issue 12, pp. 2533-2550. DOI: https:/ / doi.org/10.1080/1369183X.2018.1561063

Jacobsen, K. (1996). Factors influencing the policy responses of host governments to mass refugee influxes. International migration review, 30(3), 655-678.

Chambers, R. (1986). Hidden losers? The impact of rural refugees and refugee programs on poorer hosts. International migration review, 20(2), 245-263.

Martin, A. (2005). Environmental conflict between refugee and host communities. Journal of peace research, 42(3), 329-346

Jacobsen, K. (2002). Can refugees benefit the state? Refugee resources and African statebuilding. Journal of Modern African Studies, 577-596.

Riyanto, S. (2004). Urgensi Legislasi Hukum Pengungsi dan Kendalanya di Indonesia. Indonesian J. Int'l L., 2, 67.

Krustiyati, A. (2012). Kebijakan Penanganan Pengungsi di Indonesia: Kajian dari Konvensi Pengungsi 1951 dan Protokol 1967. Law Review, 12(2), 171-192.

Syahrin, M. A. (2019). Dimensi Hak Asasi Manusia Dalam Penanganan Kasus Pengungsi Rohingya: Pendekatan Hukum Interdisipliner. Lex Librum: Jurnal Ilmu Hukum, 5(2), 897912.

Syahrin, M. A. (2019). Kepastian Hukum Dan Kekuatan Bangsa.". Petak Norma, 4(2), 1-4.

Atik Krustiyati. (2008). Aspek Hukum Internasional Penyelesaian Pengungsi Timor Leste Sebagai Upaya Peningkatan Hubungan Bilateral Antara Indonesia Dan Timor Leste. Jurnal Yustika, Vol.II, No.1-juli 2008 
Atik Krustiyati. (2012). Kebijakan Penanganan Pengungsi di Indonesia: kajian dari konvensi pengungsi Tahun 1951 dan Protokol 1967. Law Review, Vol. XXI, No. 2. Fakultas Hukum Universitas Surabaya 